\title{
Legal Protection for Tourists on Trips to Bali
}

\author{
I Gusti Ngurah Dhian Prismanatha ${ }^{1}$, I Made Sepud ${ }^{2}$ and I Gusti Bagus Suryawan ${ }^{3}$ \\ \{dhian.prismanantha@gmail.com ${ }^{1}$, sepud.made@gmail.com² and suryawanmeraku@gmail.com ${ }^{3}$ \} \\ Universitas Warmadewa, Denpasar, Bali - Indonesia
}

\begin{abstract}
With the perspective of Indonesian law, this paper examines forms of legal protection for tourists who travel in Bali as well as examines legal liabilites of the Travel Bureau toward tourists who do not enjoy their trips. This study was realized in the design of empirical legal research based on the gap between legal provisions in Article 26 letter $\mathrm{d}$ of the tourism law and contradictory situations provided by travel service agent. The results show that legal protection for tourists on tourist trips is preventive and repressive, focusing on providing security and comfort for tourists. Legal responsibility by the Travel Agency that provides the best servants for tourists is an absolute responsibility where the travel agency will upgrade the service and do refunding.
\end{abstract}

Keywords: Legal protection; liability; tourist; travel bureau; trip

\section{Introduction}

Indonesian tourism is performed with several principles: upholding religious norms and cultural values as part of the concept of life in the balance of relations between man and God Almighty, the relationship between humans and fellow humans and the relationship between humans and the environment; upholding human rights, cultural diversity and local wisdom; providing benefits for people's welfare, justice, equality and proportionality; preserving nature and the environment; empowering local people; ensuring integration between sectors and regions, between centers and regions which are a systemic entity within the framework of regional autonomy, as well as integration among stakeholders; and complying with the world tourism code of ethics and international agreements in the tourism sector [1] [2] [3]. Article 14 of the Republic of Indonesia Law Number 10 of 2009 concerning Tourism determines that tourism businesses that can be carried out in the entire territory of Indonesia include tourist attractions, tourism areas, tourism transportation services, tourist travel services, food and beverage services, providing accommodation, organizing entertainment and recreation activities, organizing meetings, intensive trips, conferences, exhibitions, tourism information services, tourism consulting services, tour guides and water and spa tours.

The tourism industry can be seen as a subsystem of the tourism system as a whole. The structure of the tourism industry starts from the travel generating region, from which prospective tourists will plan a tour. The tourism industry subsystem will continue along the transit points/lines that include airline services and accommodation during flight transit [4]. A travel service business called a tourism business is the organization of a Tourist Travel Bureau and a Travel Agency [5]. Meanwhile, what is meant by a travel agency is an effort to provide travel planning services and/or tourism services, including the administration of religious trips [5].

Tourism business activities in Badung Regency have potential tourism objects to be developed and are very attractive to tourists and foreign tourists to visit, including Uluwatu, 
Pandawa Beach, Kuta Beach, Nusa Dua Beach, Monkey Forest Sangeh, Taman Ayun Temple, Tanjung Benoa, Nung-nung Waterfall, Plaga village, Baha Village. Throughout, Bali there are 404 Travel Agencies that have been registered as members of the Association of Indonesian Tours and Travel Agencies (ASITA). The rapid progress occurred in tourism activities in Bali, especially in Badung Regency, resulted in travel agents having to work hard to provide tourism services to tourists by prioritizing comfort and safety in traveling.

In Article 26 letter (d) of the Tourism Law it is stipulated that every tourism entrepreneur is obliged to provide comfort, hospitality, and security and safety protection for the tourists. However, if examined more closely, the article offers very principled doubts in its interpretation, that is, the lack of specificity of the liability of travel agents for actions that do not seek to provide comfort, hospitality, security protection, and safety for tourists on their journey. Therefore, it is compulsory if the state must regulate the liabilities of the service provider after the duties and responsibilities for them are stipulated in the national law [6]. The question is to what extent it is the responsibility of travel service providers when it comes to security guarantee for tourists who get travel services from them? As an illustration, one of the companies engaged in the provision of tourist travel services, namely, say it a pseudonym, PT. HK. In interviews conducted with tourists who had used company services, it was dismissed that the inconvenience had been felt when making a reservation. The traveler claimed that the reservation ordered and provided by tourism services was not in accordance with the initial agreement, that it gave rise to a feeling of discomfort in the tour. In conclusion, the emergence of problems that occur in the world of tourism, especially tourism, indicates that the laws and regulations are not implemented properly by tourism actors, so tourism activities are disturbed by undesirable things. What is more important is that, the tourism law only determines administrative sanctions for every tourism entrepreneur as stated in Article 63 of the tourism law, namely that every tourism entrepreneur does not fulfill the provisions of article 26 in the form of: a. written warning, b. restrictions on business activities; and c. temporary freezing of business activities. From the provisions, an urgent question appears to be asked. What if tourists feel materially and immaterial loss as a result of not fulfilling the obligations of the travel agent business as referred to in article 26 of the tourism law? Indiscriminate actions can occur, such as the debate between demanding tourists and agents of tour travel services who are not given a fixed liability in taking responsibility for a situation where tourists feel a lack of comfort and security in their journey. This is a legal loophole that requires the touch of scientific studies.

In this study, we deal with legal protection for travelers on the trip provided by travel agents and to reveal it and to review the liabilities of travel agents in guaranteeing security, comfort and satisfaction of tourists who use their services.

This study was carried out by utilizing empirical legal or socio-legal research design. The vacuum of the legal provisions governing the liabilities of travel agents is the starting point in the launch of this study. The gap is seen in the existence of a rule that states that a tourist travel service business is obliged to provide services to tourists who use their services. While in practice, not all Travel Agencies provide services that are in accordance with what has become an agreement when tourists use their services. In other words, tour packages offered sometimes do not match what is offered.

As we deal with normative law study, we made use of statute approach, historical approach, factual approach, and cases approach. What we mean by these approaches are we conducted investigations on existing stipulated norm rules of Indonesia regulating the tourism, the tourists, and the incumbencies of travel agents oriented to tourists or tour service satisfaction manifested in tourists' comforts and safeties. Data were collected by interview 
methods conducted to 10 tourists who had used tour services from the city of Denpasar. The things that were asked in this interview were the satisfaction and dissatisfaction of the tourists for the tourist travel services they purchased from Denpasar and the reasons. In realizing the legal approaches mentioned earlier, we conducted library investigations to obtain theories or literature relating to travel and the provision of tour services. Data were processed qualitatively, i.e. information obtained from the interview results is described on words and by interpretations by looking at their close relationships with Indonesian Law governing the travelling.

\section{Results and Discussion}

\subsection{Regulation of Tourism in Indonesian National Law}

Tourism is a big industry of the country and therefore regulations need to be regulated to meet the demands of legal certainty. In Indonesia, to meet the demands of legal certainty and economic needs, the government issued Law Number 10 of 2009 concerning Tourism which is called the Tourism Law. This law comes into force on the date it was issued, i.e on January 16, 2009. Law Number 10 of 2009 concerning Tourism is contained in 27 chapters and 70 Articles.

Referring to the provisions of article 2 of the Tourism Law, tourism is carried out based on the principle of benefit, kinship, fairness and equality, sustainability, independence, sustainability, participatory, sustainable, democratic, equality and unity. Meanwhile, the purpose of organizing tourism as stipulated in Article 4 of the Tourism Law is to: (1) Improving economic growth (2) Improving people's welfare (3) Eradicating poverty (4) Overcoming unemployment (5) Preserving nature, environment and resources (6) Promoting culture (7) Concerning the nation's image (8) Cultivating a sense of love for the homeland (9) Strengthening national identity and unity and (10) Strengthening friendship between nations [7].

One of the differences between the current Tourism Law and Law No. 9 of 1990 is the recognition of the right to travel as part of Human Rights (HAM). Developing countries generally still take into consideration the field of human rights relating to the right to travel. This is different from the conditions in developed countries, such as the European Union (the EU); they are quite attentive and one of the focuses of their concentration is the right of everyone to travel (the right to tourism) that is associated with the quality of human life [8].

Furthermore, Article 19 paragraph 1 point (a) of the Tourism Law stipulates that every person has the right to have the opportunity to fulfill tourism needs. Recognition of Human Rights in tourism activities is a representation of recognition of the economic and social rights of the community. In turn, this condition will revive the tourism business, which was once deteriorated by the growing enthusiasm of the people, both domestic and international to travel. As a result, tourism businesses in Indonesia will continue to survive in the face of a mounting wave of competition as an impact of service liberalization.

\subsection{Regulation of Legal Protection of Tourists under Indonesian Legislation}

Legal protection for tourists is an important aspect of tourism development, given that tourism activities that focus on safeguarding tourist safety, environmental preservation and quality, or order and peace of the people held based on applicable legal provisions are urgent in an effort to advance the world of tourism [2]. If a country of a tourist destination cannot 
provide a sense of security, orderliness and cannot provide adequate safety and services for tourists, it will be shunned by considerable number of tourists, and in turn, these conditions greatly affect the development of tourism to be bad in the country. The increase of the progress of national tourism, which is marked by an increase in quantity of the visiting tourists to Indonesia, needs to be maintained by providing maximum legal protection for them to maintain their security and safety from the possibility of adverse actions or events.

Today, every country, including Indonesia, is trying to provide tourism facilities and infrastructure [1]. However, this effort will not be good if it does not lead to creating a sense of security and comfort for tourists. In the era of globalization, legal protection for users of tourism services and tourism entrepreneurs is also urgent. The provisions of Article 20 (c) of the tourism law unite "Every tourist has the right to obtain legal protection and security." The tourism entrepreneur, according to the provisions of Article 26 paragraph (d), is obliged to provide comfort, hospitality, protection of security and safety of tourists. In addition, the government and regional government according to the provisions of Article 23 paragraph (1) $\mathrm{a}$, are obliged to provide tourism information, legal protection, and security and safety to tourists. Unfortunately, what was found in this study was that there were several complaints from tourists who had been tourism service users in the Badung region. The complaints were the received tour services provided to them in contrast to the provisions of Law Number 10 of 2009 concerning Tourism, specifically Article 20 C, namely the comfort and safety of tourists in carrying out travel. More importantly, in addition to Law No. 10 of 2009 concerning Tourism, legal protection of the rights of tourists as consumers is also regulated in Article 4 of Law No. 8 of 1999 concerning Consumer Protection. The referred consumer rights are the right to comfort, security and safety in consuming goods and/or services (Article 4 letter a). Additionally, the right to obtain advocacy, protection and efforts to resolve consumer protection disputes are also properly stipulated $\{$ Article $4(\mathrm{e})\}$.

The nature of legal protection against actually centered on the interests of the safety of people who are given protection. This is in line with the notion of protection proposed by Rahardjo, that is to say, legal protection is an effort that involves the matter of protecting one's interests by allocating a power to him to act in the context of his interests [9]. In line with this, Hadjon argues that legal protection is an action to protect or provide assistance to legal subjects, using legal instruments. Thus, the provisions of Law No. 10 of 2009 and Law No. 8 of 1999 should be a form of effort to protect and regulate the rights and obligations of tourists as consumers of tourism services. Protection of tourists must be fostered in order to allow the state to be one the main destinations for foreign tourists. Otherwise, the negative impact that brings huge losses to the country will be caused since tourism is the economic breath of the country itself.

Juridically, the legal product that can be observed related to the regulation of legal protection against tourists is Law No. 10 of 2009 concerning Tourism. The provisions of Article 20 letter $\mathrm{c}$ of this law stipulate that every tourist has the right to obtain legal and security protection. In this regard, national economic development must be able to support the growth of the business world so that it can produce a variety of goods and/or services that can improve the welfare of many people [10].

\subsection{Liability of Travel Agency toward Tourists}

\section{Travel Bureau in Tourism}

In the world of tourism there are several terms, namely tour operator, travel agency, and travel bureau. The term is equated with the term Tour Travel Bureau in Indonesia [11]. The 
terms that may be different, but if viewed in the meaning, all terms have the same meaning. All of that is a function of the Tour Travel Bureau [12].

The coverage for the Tour Travel Bureau in Indonesia as contained in the Government Regulation of the Republic of Indonesia No. 67 of 1996 concerning the Organization of Tourism, in CHAPTER II Paragraph 1 is: companies in the form of limited liability companies or cooperations that carry out tourism travel business activities which cover three main businesses that must be carried out, namely: (1) planning and packaging of tour components, which include tourism facilities, tourist objects and attractions and other tourism services, especially contained in the territory of Indonesia in the form of tour packages; (2) organizing and selling tour packages by distributing them through Tourism Travel Agents and/or selling them directly to tourists or consumers; and (3) providing tour guide services related to tour packages sold.

The Travel Bureau is responsible for the safety of tourists traveling on tours based on the tour packages it sells. Based on these provisions, some of the business activities that can be carried out by the Travel Bureau in the sense of being a tourism industry concisely include:

a) A travel agency is a company or business entity that has the authority to provide tour packages and has the right to sell and organize such tour packages.

b) The travel agency also provides transportation for people or groups of people who use tour package services or services it provides.

c) The travel agency is also entitled to serve orders from people or groups of people about lodging, restaurants, or other tourist facilities needed.

d) The travel agency takes into accounts of the letters from a tourist trip and also has the right to organize a guiding tour.

The last liability carried out by a travel agency in organizing a tour package is to provide comfort and security to the person or group of people who use the services of the tour and travel agency.

Based on the business activities carried out by the Tourist Travel Bureau as described, the conclusion is what Yoeti claims, that is to say, the main business activities of the travel agency, in essence, involve two cores: first, planning and secondly, organizing people's trips people for tours on their own initiative and risk, with the aim of taking advantage of the operation of the trip [13]. Therefore, as a planner and organizer of tourist activities, the Travel Bureau holds two functions, namely: General function. Here, a travel bureau is a company or business entity that provides information or information about everything related to the world of travel in general and travel in particular.

Special function. Here, a travel bureau holds three functions consecutively, namely: 1) it is as an intermediary between tourists and companies providing tourist travel facilities, which are needed by tourists to reach tourist destinations. In its activities it acts on behalf of other companies and sells the services of the companies it represents; 2) it plays a role of a company or a business entity that plans and organizes tours with its own responsibilities and risks; and 3 ) it plays the role of an organizer, that is, it is in the midst of the tourism industry, intensifying business [14], actively cooperating with other companies both at home and abroad, to make special agreements that regulate work relations with tourist companies so that the duties, obligations and the rights of each party.

\subsection{Liabilities of Travel Bureau toward Tourists}

In essence, travel service business, in this case is a travel agency, is a type of business that relies on trust [15]. Trust is usually obtained in the form of payment in advance and through a promise that a service user will obtain services that have never been obtained in advance, as 
well as the trust on a transportation and hospitality business that provides services on a credit basis [8]. In short, it can be said that the trust of tourists or service users is the main capital for the sustainability of a business engaged in services. As previously stated, tour packages are one of the products produced by the Travel Bureau.

In carrying out its business, business operators of the Travel Bureau are required to carry out surveillance efforts on tourism packages that have been produced, whether they are in accordance with what happened in the implementation or not. This is also determined in the Minister of Tourism and Creative Economy Regulations (hereinafter referred to as Permenparekraf) of Indonesia Number 4 of 2014, in article 17. In this law, the parties responsible for supervising tourist travel business certification services are regulated, that is

(1) The Minister/Governor/Regent/Mayor supervises the implementation and fulfillment of the Tourism Travel Business Standards, according to his authority.

(2) Supervision carried out by the Minister as referred to in paragraph (1) through evaluating the application of the standard of Travel Tourism Services.

(3) Supervision carried out by the Governor as referred to in paragraph (1) through evaluation of reports on the activities of applying the standard of Tourism Travel Services in the work area.

(4) The Regent/Mayor conducts supervision as referred to in paragraph (1) through evaluation of the Basic Requirements, and ownership of the Tourist Travel Business Certificate.

Furthermore, if the business actor does not implement and/or violate the provisions referred to in Article 7 paragraph (1) and Article 13, they shall be subject to administrative sanctions, as stated in Article 18 paragraph (2) to (5) of this Ministerial Regulation, namely:

(1) Administrative sanctions as referred to in paragraph (1), in the form of: (a) written warning; (b) restrictions on tourist travel business activities; and (c) freezing or revocation of Tourism Business Registration Lists.

(2) Administrative sanctions in the form of written warning as referred to in paragraph (2) letter a shall be carried out at least 3 (three) times and carried out appropriately and in an orderly manner, with the fastest interval between each written warning for 30 working days, and must be imposed before other administrative sanctions are imposed.

(3) The restriction of Tourism Travel Services as referred to in paragraph (2) letter b, shall be imposed if the Tourism Entrepreneur does not comply with the third written warning and the period of the interval as referred to in paragraph (3) for a maximum of 30 working days, has been exceeded.

(4) Freezing or revocation of the Tourism Business Register as referred to in paragraph (2) letter c, shall be imposed if the Tourism Entrepreneur does not comply with the third written warning and has passed the maximum period of 60 (sixty) working days, starting from the date of reprimand third written is worn.

The provision of administrative sanctions indicates that this certification is an absolute requirement that must be owned by the Travel Bureau in carrying out its business. Because a travel agency is an intermediary between tourism entrepreneurs and tourists, they have a responsibility to provide products, services and management that are in accordance with the standards. In line with the ideas put forward by Algra et al., actually liability is the obligation to assume the responsibility suffered (if prosecuted), both in law and in the administrative field. In line with the idea, in relation to the tourism package provided, Atherton and Atherton [15] had once claimed that in tourism, travel and hospitality, consumers are particulary vulnerableunder the old common law rules. The product is usually intangible (consider, for 
example, a package holiday) and often distributed throughintermediaries. There is usually no opportunity to look, see, touch, feel or sample the productbefore purchase or consumption ... the product is usually delivered, used and consumed all at the same time." Supported by these ideas, the existence of certification is not an optional thing because the resulting tour package usually cannot be tried beforehand in advance to being purchased by tourists. Meanwhile, in relation to those responsible for tour packages, travel agents hold a central position, as also stated by Atherton and Atherton, it is that: (1) The Tour Operator is the mere agent. In this opinion, it is claimed that the tour and travel agency are only an agent who undertakes to regulate a service that will be carried on by another party. This is the definition of tourism travel agency services in a narrow sense, which also shows that the travel agency's responsibilities are also narrow; (2) The Tour Operator is the principal contractor. In this opinion, tour operators are the main contractors who undertake to provide a service that will be forwarded by them or carried out by other parties. This opinion shows the responsibility of travel agents in a broad sense. This involved the main responsibility of the tour and travel agency in ensuring the tourism service package provided, whether appropriate with the right expertise or not.

With regard to the travel agency's responsibilities in the context described in the ideas above, Article 26 letter $\mathrm{d}$ of the Tourism Law prescribes that every tourism entrepreneur is obliged to provide comfort, hospitality, security and safety protection for tourists. This means that the obligation of a travel agent in order to travel tourists is absolute. Thus, a travel agency is charged a liability to tourists to provide satisfactory services with exhaustive protection to tourists, the users of their services.

Compared to Kelsen's theory of responsibility, the nature of a responsibility can be realized in two forms, i.e.:

(1) Responsibility based on misconducts. This kind of responsibility is borne by the legal subject or the perpetrator who commits an act against the law or a criminal act, caused by a mistake or negligence.

(2) Absolute responsibility. This responsibility is borne by a person if his actions have a consequence that is deemed detrimental to the legislator, and there is a relationship between the action and the consequences resulted. The principle of absolute responsibility is a system of responsibility that is not based on the manufacturer's fault, namely applying responsibility to the party who sells the defective product, without any burden to the consumer or doubtful party to prove the error.

From the results of interviews with a travel service provider PT Kristal Holidays, it was found that one of the efforts to protect tourists who feel inconvenience when using travel services from them is to review and evaluate travel packages that have been sold and then to make improvement if there are errors, also refunding and upgrading in service for the convenience of tourists. In conclusion, the responsibility charged by the state to a tour and travel agency, based on Permenparekraf Number 4 of 2014, is absolute responsibility. That said, because the result of not implementing standard travel certification as stipulated in the Permenparekraf is the occurrence of losses to tourists who use goods and/or services. In addition, these conditions can also because losses suffered by consumers of service users.

\section{Concusion}


Legal protection for tourists in travel is important. The Travel Agency as an agency providing travel services has a great responsibility to provide protective, safe and comfortable travel services, and hospitality-centered services. In Indonesia, tourism travel is specifically regulated by the state in its Laws. Thus, legal protection for tourists on tourist trips is regulated in Article 20 c of Law Number 10 of 2009 concerning Tourism which states the rights and obligations of tourists for security and protection. In addition, legal protection for tourists visiting Indonesia is realized in two forms of protection: preventive and repressive.

Liability of the Tourist Travel Bureau for tourists is an absolute responsibility charged by the state, which is regulated through Permenparekraf (Minister of Tourism and Creative Economy Regulation) Number 4 of 2014; realized in service upgrading and refunding if an error occurs.

Looking at the context of the scope of this study, the government should conduct intensive supervision of tour and travel agents related to tourism so that travelers' safety and comfort is guaranteed. The Travel Bureau should pay attention to the legislation related to tourism in order to better guarantee safety, comfort and safety for tourists.

Acknowledgements The authors express the greatest gratitude to the organizing committee of the International Conference on Social Sciences (ICOSS) of Universitas Warmadewa for the great contribution that has been granted to the launching of this scientific script at EAI Publisher. Hopefully the ideas found in the paper can be additional theoretical and practical for many parties.

\section{References}

[1] S. M.: The Existence of Religious Norm in the Formulation of Local Regulations in Indonesia. Int. J. Humanit. Soc. Sci. Vol. 3 (7). pp. 194-203 (2013)

[2] Jaelani, A.: Halal tourism industry in Indonesia: Potential and prospects. MPRA. no. January (2017)

[3] Syamsul.: Attitudes to Human Rights and Freedom of Religion or Belief in Indonesia. Yogyakarta: Kanisius (2010)

[4] Pitana, I, G and Diarta, I, K, S.: Pengantar Ilmu Pariwisata. Yogyakarta: CV. Andi offset (2009)

[5] Pasal 1 Angka 2 Peraturan Menteri Kebudayaan dan Pariwisata Nomor: PM.85/HK. 501/MK.P/2010 Tentang Tata Cara pendaftaran Usaha jasa Perjalanan Wisata. .

[6] Yusa, I, G.: Identification And Analysis Of The Rights Of Indigenous Peoples In The Study Of Constitutional Law. Const. Rev. Vol. 2 (1) (2016)

[7] Widiatedja, I, P.: Liberalisasi Jasa Dan Masa Depan Pariwisata Kita. Denpasar: Universitas Udayana (2010)

[8] Ketut, S, D, N and A. Et.: The Right To Tourism Dalam Perspektif Hak Azasi Manusia. J. Ilm. Kertha Patrika. Vol. 36. pp. 3-4 (2011)

[9] Rahardjo, S.: Sisi-sisi lain dari hukum di Indonesia. Jakarta: Kompas (2003)

[10] Widjaja, G and Yani, A.: Hukum Tentang Perlindungan Konsumen. Jakarta: PT. Gramedia Pustaka Utama (2003)

[11] http://raymondfrans63.wordpreess.com/biro-perjalanan-wisata aktvitasnya/.Diakses tanggal 17 Januari 2018.

[12] Römhild, R.: Culture and Society in Tourism Contexts. Tour. Soc. Sci. Ser. vol. 17. pp. 141$158(2012)$

[13] Yoeti, O, A.: Pengantar Ilmu Pariwisata. Bandung: Angkasa (1987)

[14] Wang, F, F.: Domain names management and legal protection. Int. J. Inf. Manage. Vol. 26 (2). 
pp. 116-127 (2006)

[15] Atherton , T, C and Atherton, T, A.: Tourism, Travel and Hospitality Law. Australia: LBC Information Services. 